\title{
Facial emotion recognition deficits in relatives of children with autism are not associated with 5HTTLPR
}

\section{Prejuízos no reconhecimento de emoções faciais em parentes de primeiro grau de portadores de autismo não são associados com o polimorfismo 5HTTLPR}

\author{
Maila de Castro Lourenço das Neves, ${ }^{1}$ Fabien Tremeau, ${ }^{2}$ Rodrigo Nicolato, ${ }^{3}$ Hélio Lauar, ${ }^{4}$ Marco Aurélio \\ Romano-Silva, ${ }^{3}$ Humberto Correa ${ }^{1,3}$ \\ ${ }^{1}$ Molecular and Biochemistry Pharmacology Program, Universidade Federal de Minas Gerais (UFMG), Belo Horizonte, MG, Brazil \\ ${ }^{2}$ New York University School of Medicine, New York, NY, USA \\ ${ }^{3}$ Mental Health Department, Universidade Federal de Minas Gerais (UFMG), Belo Horizonte, MG, Brazil \\ ${ }^{4}$ Instituto Raul Soares, Belo Horizonte, MG, Brazil
}

Abstract

Objective: A large body of evidence suggests that several aspects of face processing are impaired in autism and that this impairment might be hereditary. This study was aimed at assessing facial emotion recognition in parents of children with autism and its associations with a functional polymorphism of the serotonin transporter (5HTTLPR). Method: We evaluated 40 parents of children with autism and 41 healthy controls. All participants were administered the Penn Emotion Recognition Test (ER40) and were genotyped for 5HTTLPR. Results: Our study showed that parents of children with autism performed worse in the facial emotion recognition test than controls. Analyses of error patterns showed that parents of children with autism over-attributed neutral to emotional faces. We found evidence that 5HTTLPR polymorphism did not influence the performance in the Penn Emotion Recognition Test, but that it may determine different error patterns. Conclusion: Facial emotion recognition deficits are more common in first-degree relatives of autistic patients than in the general population, suggesting that facial emotion recognition is a candidate endophenotype for autism.

Descriptors: Autistic disorder; Emotion; Neurosciences; Genetics; Family

\section{Resumo}

Objetivo: Diversos estudos sugerem que o processamento de emoçôes faciais está prejudicado em portadores de autismo e que tal prejuizo possa ser hereditário. Nós estudamos o reconhecimento de emoções faciais em parentes de primeiro grau de portadores de autismo e suas associaçōes com o polimorfismo funcional de transportador de serotonina (5HTTLPR). Método: Foram avaliados 40 parentes de primeiro grau de portadores de autismo e 41 controles saudáveis. Todos os participantes foram submetidos ao Teste de Reconhecimento de Emoçôes (ER40) da Bateria Neuropsicológica Computadorizada da Universidade da Pensilvânia (PENNCNP) e genotipados para o 5HTTLPR. Resultados: Os parentes de primeiro grau de portadores de autismo apresentaram pior reconhecimento de emoçôes faciais comparados aos controles. A análise do padrão de erros mostrou que eles tendiam a reconhecer faces demonstrando emoçōes como neutras. O genótipo para o 5HTTLPR não influenciou a acurácia no Teste de Reconhecimento de Emoçôes, mas os homozigotos para $o$ alelo $L$ apresentaram padrão de erros diferente. Nossos resultados sugerem que prejuizos no reconhecimento de emoçōes faciais possam ser encontrados em maiores taxas em parentes de primeiro grau de autistas do que na população em geral. Conclusäo: Nossos resultados sugerem que o reconhecimento de emoçôes faciais seja um candidato a endofenótipo no estudo do autismo.

Descritores: Transtorno autístico; Emoçôes; Neurociências; Genética; Família

\section{Introduction}

Autism is a pervasive neurodevelopmental disorder with an early onset in childhood characterized by qualitative alterations in many domains including social reciprocity, communication, restricted interests and by the presence of repetitive and stereotyped behaviors. ${ }^{1}$ The etiology of autism is not yet well understood, but there is much evidence showing that genetics possibly accounts for an important part of it. ${ }^{2,3}$ Such evidence comes from epidemiologic genetic studies, mainly twin studies, which showed an autism heritability of about $90 \%$, one of the highest among all neuropsychiatric disorders. ${ }^{1,2}$

Despite this high heritability, the identification of genes linked to autism has been a difficult endeavor: genome scans have not been
Submitted: June 2, 2010

Accepted: January 10, 2011

\section{Correspondence}

Humberto Correa

Faculdade de Medicina, UFMG

Avenida Prof. Alfredo Balena, 190

Belo Horizonte, MG, Brazil

Phone/Fax: (+55 31) 3409-9785 / 3409-9786

E-mail: correa@task.com.br 
able to find regions of genome-wide significance, and association studies still are, at best, inconclusive. ${ }^{4}$ This can be explained by the complex model of inheritance of neuropsychiatric disorders like autism, where multiple alleles, generally displaying small effects, interact with one another and with the environment to cause diseases. In fact, the number of genes estimated to contribute to autism can be over $100,{ }^{2}$ and possibly any individual gene makes only a small contribution to the entire autism phenotype. In addition, we can speculate that the most-used phenotype, the Diagnostic and Statistical Manual of Mental Disorders, Fourth Edition (DSM-IV) diagnosis, may not be adequate for molecular studies and that a new approach might be required to better identify autism vulnerability genes.

An interesting approach to circumvent some of those difficulties comes from the endophenotype concept proposed by Gottesman and Shield (1972), which has been a matter of renewed interest in recent years. Endophenotypes are quantitative, heritable, trait-related deficits typically assessed by laboratory-based methods rather than clinical observation. ${ }^{5}$ Endophenotypes are seen as lying more closely to genetic variations than to complete phenotypes. ${ }^{6,7}$ In this context, the endophenotype strategy offers opportunities to understand the genetic basis of mental disorders. The reasonable criteria for a viable and generative endophenotype are as follows: (1) the deficits in the endophenotype are associated with psychiatric disorders; (2) the deficits are heritable; (3) the endophenotype deficits are stable; (4) the endophenotype and disorder show co-segregation; and (5) any specific endophenotype deficit is found at higher rates among patients' relatives than in the general population. ${ }^{5-7}$

Since the initial description of autism by Kanner (1943), problems in social and emotional reciprocity are considered a hallmark of the illness. ${ }^{89}$ An important component of both social interaction and emotional reciprocity is face processing. In fact, the face is probably the most important conveyor of emotional information, and many components of face processing seem impaired in autism, such as gaze processing, ${ }^{8}$ face recognition memory ${ }^{8}$ and recognition of facial emotion expressions. ${ }^{8-15}$ Interestingly, some studies found a high prevalence of deficits in social and communicative behaviors in relatives of individuals with autism. ${ }^{13,16,17}$ Bolte and Poutska found a tendency for subjects from multiplex families with autistic loading to score lower on the test of facial emotion recognition than individuals from simplex families with autistic loading. ${ }^{13}$ Adolphs investigated face processing by using a method known as the "bubbles", which measures how viewers make use of information from specific facial features in order to judge emotions. They described that parents of autistic children showed a remarkable reduction in processing the eye region in faces, together with enhanced processing of the mouth, compared to a control group of parents of healthy children. This pattern of face processing was previously reported to occur in autism and in siblings of autistic children. ${ }^{16,17}$ These findings provide a window into the endophenotype that may result from a subset of the genes that contribute to social cognition. ${ }^{16,18,19}$
A widely studied functional polymorphism in the promoter region of the serotonin transporter (5HTTLPR), exhibiting two different alleles (one long, L, and one short, S), emerges as a strong candidate to be associated with facial emotion recognition in autistic subjects and their relatives. Serotonin plays a central role in the processing of emotion, as evidenced by brain serotonergic abnormalities in emotional disorders and the therapeutic efficacy of drugs targeting this system. ${ }^{20}$ Moreover, 5HTTLPR genotypes impair the functional connectivity of the amygdala and ventromedial prefrontal cortex (VMPFC) circuitry, which is essential for the expression and regulation of emotion. ${ }^{20-23}$ Second, some studies have shown an association between 5HTTLPR and neuroticism, anxiety, and stress reactivity, suggesting that this can be an important genetic variation in human behavior. ${ }^{21}$ Third, some studies reported an association of 5HTTLPR with autism. ${ }^{4}$ However, which allele (short or long) was associated with autism varied across studies, possibly due to the great heterogeneity of autism itself, ${ }^{1}$ as well as to the ethnic heterogeneity seen in some studies. ${ }^{24}$ Finally, 5HTTLPR has also been studied in association with emotion processing in autism. Tordjman found an increased severity in the Autism Diagnostic Interview - Revised combining the social/communication domain and the conversation subdomain in subjects with the short 5HTTLPR allele. ${ }^{25}$ Brune found that nonverbal communication was more severely affected in the short allele group and that the long allele was associated with increased difficulties to direct facial expressions in the Autism Diagnostic Observation Schedule Scale. The heterogeneity of these results points to the necessity of more research to elucidate the influence of 5HTTLPR in emotional processing.

This study investigates the recognition of facial emotion in relatives of autistic patients compared with healthy controls, using the Penn Computerized Neuropsychological Battery, and more specifically the Penn Emotion Recognition Test (ER40). ${ }^{7}$ Furthermore, we investigated the association between the allelic polymorphism 5HTTLPR and the recognition of facial emotion. We hypothesized that the recognition of facial emotion could be used as an endophenotype for autism, that the recognition of facial emotion would be impaired in first-degree relatives of patients with autism, and that the short allele (S) might be associated with such deficits.

\section{Method \\ 1. Participants}

Forty parents (30 mothers and 10 fathers) of 30 children with autism, and forty-one non-patient control participants (28 women and 13 men), all self-reported Caucasian-Brazilian, were enrolled in the study. The diagnosis of autism in children was made by a psychiatrist following DSM-IV criteria. After a full explanation of the study, all participants provided written informed consent to participate. The study was approved by our local ethics committee in Universidade Federal de Minas Gerais (ETIC 0028/06).

To be enrolled, subjects had to be between 18 and 65 years old and to have at least six years of formal education. Subjects in 
the percentile below 25 on the Raven Progressive Matrices and illiterate subjects were not enrolled.

All participants were further evaluated by a psychiatrist using a structured diagnostic instrument, the Mini International Neuropsychiatry, ${ }^{26}$ based on DSM-IV criteria. Participants with an axis I diagnosis were not enrolled $(n=7)$. The study took place at Raul Soares Hospital, Minas Gerais, Brazil, from March to December of 2009.

\section{Facial emotion recognition assessment}

Participants were tested in a silent room, and facial stimuli were presented on a computer screen.

The ER40 is a computerized test that assesses categorical identification of facial expressions of emotion ${ }^{27}$ and lasts about 15 minutes. Subjects are asked to choose, using the computer mouse, the most appropriate emotion label from a list of five (happiness, sadness, anger, fear, or no emotion). Forty square photographs with eight actors with hair were used: eight neutral expressions, four emotional expressions of low intensity, and four emotional expressions of high intensity for each of the four emotions. Across emotional categories, stimuli were balanced for posers' gender and ethnicity, with 21 white and 19 non-white faces. The test measures the subject's response time. The validity of the test has been previously evaluated ${ }^{28}$ in an English population.

\section{Face memory assessment}

The Penn Facial Memory Test (PFMT) was used to measure memory to facial displays. The test lasts about 10 minutes. In the first part of the test, the participants were shown 20 faces, which they were asked to memorize. Later, participants were shown these 20 faces and 20 new faces, presented in a random order. The participants had to decide whether they had seen the faces presented immediately before. They had to choose, using the computer mouse, among four options: "definitely yes", "probably yes", "probably no", and "definitely no." For this memory task, all facial stimuli were black and white photographs of faces rated as having neutral expressions, balanced for gender and age. ${ }^{28}$

\section{Genotyping}

All participants were genotyped. DNA was extracted from whole blood. 5HTTLPR genotyping was performed using previously described methods. ${ }^{29} \mathrm{~S}$ allele carriers were assigned to the same group (LS + SS genotypes) since it has been proposed that this allele acts in a nearly dominant way and, functionally, the uptake of serotonin (5-HT) is approximately twofold higher in cells containing the homozygous LL form of 5HTTLPR than either the LS or SS forms. ${ }^{29}$

\section{Data analysis}

ER40 scores were compared between groups. First, we evaluated whether the scores followed a normal distribution with the Shapiro-Wilk test. The answers and median response time for correct answers in the ER40 and PFMT were used as response variables for the analyses. Since the response variable in the ER40 and PFMT had no normal distribution, we used the Mann-Whitney test to compare emotion recognition between the relatives of autistic patients and controls. We named accuracy the total of correct responses in the test. A chi-square test was used to compare genotype frequencies among the parents of children with autism and control participants.

First, we evaluated the effect of genotype for 5HTTLPR in facial emotion recognition within the two groups. Next, we evaluated the effect of genotype for 5HTTLPR in the ER40 scores of all participants using the ordinal logistic regression model. This analysis was performed to adjust for potentially confounding variables (age, education, family history for autism). Regression models were used to predict the probability of occurrence of an event by fitting data into a logistic curve, the event in question being the probability of 5HTTLPR influencing facial emotional recognition. The ordinal logistic regression was applied because we have an ordinal response variable (answers in the ER40 and PFMT). All tests were two-tailed, and the significance level was $5 \%$.

\section{Results}

The sample of first-degree relatives of autistic children comprised 30 women (75\%) and 10 men (25\%). The participants' age ranged from 21 to 61 years, with a mean of 41.5 and standard deviation of 10 . The average education was 16 years of study.

The control sample consisted of 41 participants, 28 women $(68.3 \%)$ and 13 men (31.7\%), with an average education of 16 years. The age in this group ranged between 22 and 63 years, with a mean of 38.4 and standard deviation of 12.1 .

We used the chi-square test to analyze the association between family history of autism in first-degree relatives and gender, age, and education. There were no statistically significant differences regarding gender $(\mathrm{p}=0.503)$, age $(\mathrm{p}=0.146)$ or education $(\mathrm{p}=$ 0.182 ) between the two groups.

The statistical power was calculated using the software $G^{*}$ Power, The analysis yielded a statistical power of 0.756 to compare the two groups, with alpha $=0.05$ and a moderate magnitude of effect according to Cohen's classification $=0.5$.

\section{Facial memory}

Diagnosis groups (parents of children with autism versus control participants) and genotype groups (LL versus LS + SS) did not significantly differ in terms of accuracy and median response time to correct answers in the PFMT.

\section{Facial emotion recognition}

We used univariate analysis to compare the performance in the ER40 between diagnosis groups because autistic patients' relatives and controls were statistically similar in regard to age, sex, education, and genotype distribution. We observed that the group of relatives performed worse in facial emotion recognition than controls. Emotions were not well recognized in female faces $(\mathrm{p}=0.0009)$, male faces $(\mathrm{p}=0.0019)$, and in faces expressing mild $(p=0.0032)$ and extreme emotions $(p=0.0022)$. 
Happiness was the most well recognized emotion in both groups, and accuracy improved with the intensity of emotion. In addition, age and gender were considered important co-factors in the ER40. The same pattern was previously described by other authors using the same test..$^{30,31}$

In the recognition of specific emotions, the relatives of autistic patients showed impaired recognition of anger $(p=0.0217)$, fear $(p$ $=0.0063)$, and happiness $(\mathrm{p}=0.0235)$, but not of sad and neutral facial displays (Table 1). Examining error patterns, we found that the parents of children with autism over-attributed neutral to emotional faces $(p=0.0033)$. Furthermore, the response time for correct answers was slower than the controls' $(\mathrm{p}<0.001)$ - Table 1.

Some patterns of facial emotion recognition were identified in the two groups. Both were more accurate in recognizing emotion displayed by female posers. Recognition was better for high-intensity than low-intensity expressions for all emotions, and accuracy was better for happy faces when compared with the other emotions.

\section{Genotypes}

In the group of relatives of autistic patients, 14 individuals were L homozygotes, 14 had an LS genotype, and 12 were S homozygotes. Within the control group, 9 participants were LL homozygotes, 22 had an LS genotype, and 10 were $S$ homozygotes. The genotypic distribution was also comparable between the parents of children with autism, with $\mathrm{X}^{2}=2.51$ and $\mathrm{p}=0.28$. The genotypic distribution followed the Hardy-Weinberg equilibrium in parents of children with autism $(\mathrm{p}=0.059)$ and healthy controls $(\mathrm{p}=0.636)$.
To study the influence of genotype on the ER40 we compared the $S$ allele carriers (SS and LS genotypes) and subjects with the LL genotype. No effects of 5HTTLPR in the ER40 scores were found in the group of relatives of children with autism or in controls.

Moreover, the univariate analysis of the data of all the participants together showed that some variables influenced responses in the ER40, like sex and age. Thus, we grouped all the participants $(\mathrm{n}=81)$ and performed a multivariate analysis to test the effect of genotypes in the ER40 scores, adjusting for possible confounding variables (age, years of education, and family history of autism in the first degree). We found no accuracy differences in the ER40 between the genotype groups, but we found that L homozygotes (LL genotype) had different error patterns. LL individuals tended to misrecognize some emotions, such as fear $(\mathrm{p}=0.030)$ and happiness $(\mathrm{p}=0.011)$ - Table 2 .

\section{Discussion}

We studied facial emotion recognition in parents of children with autism and in healthy parents of non-ill children, and found that parents of children with autism performed worse than the control group. Furthermore, our findings suggest that the 5HTTLPR polymorphism may influence facial emotional processing.

In order to avoid confounding factors, subjects presenting a psychiatric axis I diagnosis were excluded from the sample because impaired facial processing abilities have been described in relation with other neuropsychiatric disturbances, like schizophrenia, ${ }^{27}$ depression, ${ }^{30}$ social phobia, ${ }^{31}$ obsessive compulsive disorder, and

Table 1 - Facial emotion recognition in relatives of children with autism $(n=40)$ and healthy controls $(n=41)$

\begin{tabular}{|c|c|c|c|c|c|c|}
\hline \multirow[t]{2}{*}{ ER40 measures } & \multicolumn{2}{|c|}{ Autism relatives } & \multicolumn{2}{|c|}{ Controls } & \multicolumn{2}{|c|}{ Significance level } \\
\hline & $\begin{array}{c}\text { Mean } \\
\text { (standard } \\
\text { deviation) }\end{array}$ & Median & $\begin{array}{c}\text { Mean } \\
\text { (standard } \\
\text { deviation) }\end{array}$ & Median & $\begin{array}{l}\text { Univariate } \\
\text { analysis }\end{array}$ & $\begin{array}{l}\text { Adjusted } \\
\text { analysis }\end{array}$ \\
\hline Time for correct answers & $3182,3(1005.7)$ & 2954 & $2321.4(468.5)$ & 2303 & $p<0.001$ & $p<0.001$ \\
\hline Correct responses $(0-40)$ & $31.2(3.4)$ & 32.5 & $33.8(3.4)$ & 35 & $p<0.001$ & $p<0.001$ \\
\hline $\begin{array}{l}\text { Correct identifications in female posers } \\
(0-20)\end{array}$ & $16.1(2.0)$ & 17 & $17.4(1.9)$ & 18 & $p<0.001$ & $p<0.001$ \\
\hline $\begin{array}{l}\text { Correct identifications in male posers } \\
(0-20)\end{array}$ & $15.1(2.1)$ & 15.5 & $16.4(2.0)$ & 17 & $p<0.001$ & 0.03 \\
\hline $\begin{array}{l}\text { Correct identifications in faces with low } \\
\text { intensity of emotion }\end{array}$ & $11.3(1.3)$ & 11 & $12.3(1,9)$ & 12 & 0.02 & 0.02 \\
\hline $\begin{array}{l}\text { Correct identifications in faces with } \\
\text { extreme intensity of emotion }\end{array}$ & $13.7(1.7)$ & 14 & $14.6(1.6)$ & 15 & $p<0.001$ & 0.02 \\
\hline Correct identifications of anger $(0-8)$ & $4.3(1.3)$ & 4 & $5.0(1.5)$ & 5 & 0.02 & 0.07 \\
\hline $\begin{array}{l}\text { Correct identifications of happiness (0- } \\
8)\end{array}$ & $7.8(0.46)$ & 8 & $7.9(0.15)$ & 8 & 0.02 & 0.04 \\
\hline Correct identifications of sadness $(0-8)$ & $6.4(1.3)$ & 7 & $6.8(1.2)$ & 7 & 0.13 & 0.38 \\
\hline Correct identifications of neutral $(0-8)$ & $6.2(1.6)$ & 7 & $6.8(1.2)$ & 7 & 0.09 & 0.30 \\
\hline False positive - anger responses & $0.65(0.97)$ & 0 & $0.51(0.87)$ & 0 & 0.47 & 0.72 \\
\hline False positive - fear Responses & $1.62(1.70)$ & 1 & $1.39(1.26)$ & 1 & 0.82 & 0.93 \\
\hline False positive - happiness responses & $0.92(1.25)$ & 0 & $0.58(0.8)$ & 0 & 0.34 & 0.45 \\
\hline False positive - neutral responses & $3.05(2.0)$ & 3 & $1.75(2.0)$ & 1 & $p<0.001$ & 0.02 \\
\hline False positive - sadness responses & $2.5(1.8)$ & 2 & $1.9(1.9)$ & 1 & 0.07 & 0.27 \\
\hline
\end{tabular}


Table 2 - Comparison of the performance in the facial emotion recognition task in all study participants ( $\mathrm{n}=\mathbf{8 1}$ ) divided by the genotype of the functional polymorphism of the serotonin transporter 5HTTLPR (LL versus LS + SS).

\begin{tabular}{|c|c|c|c|c|c|c|}
\hline \multirow[b]{2}{*}{ ER40 measures } & \multicolumn{2}{|c|}{ LS/SS genotype } & \multicolumn{2}{|c|}{ LL genotype } & \multirow[b]{2}{*}{$\begin{array}{c}\text { Significance } \\
\text { level (Univariate } \\
\text { analysis) }\end{array}$} & \multirow[b]{2}{*}{$\begin{array}{l}\text { Significance } \\
\text { level (Adjustec } \\
\text { analysis) }\end{array}$} \\
\hline & $\begin{array}{c}\text { Mean } \\
\text { (standard } \\
\text { deviation) }\end{array}$ & Median & $\begin{array}{c}\text { Mean } \\
\text { (standard } \\
\text { deviation) }\end{array}$ & Median & & \\
\hline 1- Correct responses $(0-40)$ & $32.9(3.7)$ & 34 & $31.7(3.2)$ & 33 & 0.09 & 0.27 \\
\hline $\begin{array}{l}\text { 2- Correct identifications in } \\
\text { female posers }(0-20)\end{array}$ & $16.8(2.1)$ & 17 & $16.6(2.0)$ & 17 & 0.53 & 0.99 \\
\hline $\begin{array}{l}\text { 3- Correct identifications in } \\
\text { male posers }(0-20)\end{array}$ & $16.0(2.1)$ & 17 & $15.1(1.9)$ & 15 & 0.02 & 0.05 \\
\hline $\begin{array}{l}\text { 4- Correct identifications of } \\
\text { anger }(0-8)\end{array}$ & $4.8(1.5)$ & 5 & $4.3(1.3)$ & 4 & 0.16 & 0.24 \\
\hline $\begin{array}{l}\text { 5- Correct identifications of } \\
\text { fear }(0-8)\end{array}$ & $6.8(1.2)$ & 7 & $6.7(1.4)$ & 7 & 0.90 & 0.56 \\
\hline $\begin{array}{l}\text { 6- Correct identifications of } \\
\text { happiness }(0-8)\end{array}$ & $7.8(0.37)$ & 8 & $7.9(0.28)$ & 8 & 0.80 & 0.48 \\
\hline $\begin{array}{l}\text { 7- Correct identifications of } \\
\text { neutral }(0-8)\end{array}$ & $6.6(1.4)$ & 7 & $6.3(1.5)$ & 7 & 0.57 & 0.63 \\
\hline $\begin{array}{l}\text { 8- Correct identifications of } \\
\text { ssadness }(0-8)\end{array}$ & $6.7(1.3)$ & 7 & $6.3(1.2)$ & 7 & 0.11 & 0.20 \\
\hline $\begin{array}{l}\text { 9- False positive - anger } \\
\text { responses }\end{array}$ & $0.55(0.88)$ & 0 & $0.65(1.0)$ & 0 & 0.66 & 0.73 \\
\hline $\begin{array}{l}\text { 10- False positive - fear } \\
\text { responses }\end{array}$ & $1.3(1.5)$ & 1 & $1.9(1.3)$ & 2 & 0.04 & 0.03 \\
\hline $\begin{array}{l}\text { 11- False positive - happy } \\
\text { responses }\end{array}$ & $0.60(1.0)$ & 0 & $1.3(1.0)$ & 1 & 0.01 & 0.01 \\
\hline $\begin{array}{l}\text { 12- False positive - neutral } \\
\text { responses }\end{array}$ & $2.4(2.2)$ & 1 & $2.3(1.8)$ & 3 & 0.91 & 0.58 \\
\hline $\begin{array}{l}\text { 13- False positive - sad } \\
\text { responses }\end{array}$ & $2.1(1.8)$ & 2 & $2.2(2.0)$ & 2 & 0.95 & 0.64 \\
\hline $\begin{array}{l}\text { 14- Correct identifications in } \\
\text { faces with low intensity of } \\
\text { emotion }\end{array}$ & $11.8(1.7)$ & 12 & $11.7(1.6)$ & 12 & 0.87 & 0.69 \\
\hline $\begin{array}{l}\text { 15- Correct identifications in } \\
\text { faces with extreme intensity } \\
\text { of emotion }\end{array}$ & $14.4(1.7)$ & 15 & $13.6(1.6)$ & 14 & 0.01 & 0.05 \\
\hline
\end{tabular}

Huntington's disease. ${ }^{31}$ We did not assess axis II diagnoses with a structured scale, and therefore we cannot exclude the possible influence of such diagnoses in our results. Nevertheless, according to our findings, the relatives of children with autism had impaired facial emotion recognition, but unaffected memory to faces, suggesting that this impairment could be more specific and not a part of a global cognitive deficit.

The parents of children with autism showed impairments in the recognition of high arousal emotions (fear, anger, and happiness). The neural basis of facial emotion processing comprises a network of cortical and subcortical structures that includes the amygdala, which is particularly activated by high arousal emotions, ${ }^{31,32}$ and there is evidence indicating that amygdala dysfunction contributes to face processing abnormalities in autism. ${ }^{8,9,11,33-35}$ Consequently, we may speculate that the impairments in emotion recognition seen in parents of children with autism reflect impaired amygdala connectivity. Specifically during emotion recognition, fathers of autistic children show reduced fusiform gyrus activation. ${ }^{36}$ Neural activity in the fusiform gyrus was reported to be inversely correlated with social deficits in autistic subjects, ${ }^{36}$ perhaps as the result of a compensatory mechanism. More neuroimaging studies are necessary to elucidate the brain network underlying the impairments in facial emotion recognition observed in autism.

Emotion recognition and Theory of Mind (ToM) are two core components of social cognition. ${ }^{37}$ There are few studies on the relation between emotion recognition and ToM. Most, but not all, of these studies show a correlation between the performance in emotion recognition tasks and ToM in children and in adults. ${ }^{37}$ Furthermore, both processes share a common network including areas assumed to be involved in embodied simulation and perception processes as core regions: the amygdala and areas belonging to the mirror neuron system. ${ }^{37}$ However, more studies are necessary to elucidate the link between ToM and facial emotion recognition, maybe using autism and focusing in amygdala connectivity.

We found evidence that facial emotion recognition is impaired in relatives of children with autism when compared with healthy controls. Our results are in agreement with previous studies $8,10,13,16,17$ that also showed emotional impairment in relatives of children with autism, even considering that different methodologies were employed. Our results fulfill one of the criteria for an endophenotype - "specific endophenotype deficit is 
found at higher rates in the probands' relatives than in the general population" - and we suggest that facial emotion recognition should be tested as an endophenotype for autism. The search for endophenotypes is challenging and complex because there are no prior criteria for deciding if a particular element of any psychiatric illness reflects the effect of a single gene. We propose that neuroimaging could be used as an extended endophenotype connecting the pathophysiology of a given disorder and particular loci or sets of loci. ${ }^{19}$

We found evidence that 5HTTLPR did not influence accuracy in the ER40, but apparently determined different error patterns. Harmer described that 10 micrograms of citalopram improved the recognition of fear, and that the acute depletion of tryptophan worsened the recognition of fear, ${ }^{38}$ while dietary tryptophan supplementation seems to improve facial emotion recognition. ${ }^{39}$ Battaglia showed that children who have one or two copies of the short allele of 5HTTLPR appear to have a different pattern for the processing of happy, neutral, and angry expressions. ${ }^{31}$ Those data suggest an important role of the serotonergic system in facial emotion recognition. Since 5 HTTLPR can have a pivotal role in the serotonergic function, it emerges as a natural candidate gene, and our results support this view. Nonetheless, our results do not allow for conclusive statements concerning the role of 5HTTLPR in the recognition of facial emotion in relatives of autistic children, especially due to the small sample size.

Limitations of our study include the fact that we did not test the patients themselves. This can be explained by the difficulties to test emotion recognition in patients with autism, since mental retardation and behavioral disturbances are frequently present. Nevertheless, impaired facial emotion recognition in autism, as well as in Asperger Syndrome, has been previously described. ${ }^{11}$ Furthermore, the study of non-ill relatives of patients with autism may be a better approach to characterize the endophenotype than the study of the patients themselves, whose multiple deficits may obscure a unique endophenotype. ${ }^{19}$ Another limitation is the lack of further cognitive assessment in our study, including the domain of attention, to analyze the effects of general cognition on facial emotion recognition, as well as those of laterality. Finally, as in all case-control genetic studies, we must be aware of falsepositive and false-negative findings due to ethnic stratification. Our sample comprised only participants who were self-designated as Caucasian-Brazilian; however, as recently demonstrated, race as determined by self and/or clinical evaluation is a poor predictor of ancestry in Brazil and an ethnic stratification bias cannot be ruled out in this case. ${ }^{40}$

\section{Conclusion}

We showed that parents of children with autism performed worse in a facial emotion recognition test than parents of non-ill children. To our knowledge this is the first study to describe the patterns of emotional recognition in relatives of children with autism and their correlations with 5HTTLPR using the ER40. Although future research is warranted to elucidate and replicate these data, our findings suggest that impaired facial emotion recognition is a candidate endophenotype for autism.

\section{Acknowledgements}

This work was supported by Fundação de Amparo à Pesquisa do Estado de Minas Gerais (FAPEMIG, Research Foundation of Minas Gerais State-Brazil).

\section{Disclosures}

\begin{tabular}{|c|c|c|c|c|c|c|c|}
\hline $\begin{array}{l}\text { Writing group } \\
\text { member }\end{array}$ & Employment & $\begin{array}{l}\text { Research } \\
\text { grant }^{1}\end{array}$ & $\begin{array}{l}\text { Other research } \\
\text { grant or medical } \\
\text { continuous } \\
\text { education }\end{array}$ & Speaker's honoraria & $\begin{array}{l}\text { Ownership } \\
\text { interest }\end{array}$ & $\begin{array}{l}\text { Consultant/ } \\
\text { Advisory } \\
\text { board }\end{array}$ & Other $^{3}$ \\
\hline $\begin{array}{l}\text { Maila de Castro } \\
\text { Lourenço das } \\
\text { Neves }\end{array}$ & UFMG & - & - & - & - & - & - \\
\hline $\begin{array}{l}\text { Fabien } \\
\text { Tremeau }\end{array}$ & $\begin{array}{c}\text { Rockland } \\
\text { Psychiatric } \\
\text { Center }\end{array}$ & - & - & - & - & - & - \\
\hline $\begin{array}{l}\text { Rodrigo } \\
\text { Nicolato }\end{array}$ & UFMG & - & - & - & - & - & - \\
\hline Hélio Lauar & FHEMIG & - & - & - & - & - & - \\
\hline $\begin{array}{l}\text { Marco Aurélio } \\
\text { Romano-Silva }\end{array}$ & UFMG & $\begin{array}{c}\text { CNPq } \\
\text { FAPEMIG }\end{array}$ & - & - & - & - & - \\
\hline $\begin{array}{l}\text { Humberto } \\
\text { Correa }\end{array}$ & UFMG & $\begin{array}{c}\text { CNPq } \\
\text { FAPEMIG }\end{array}$ & - & - & - & - & - \\
\hline \multicolumn{8}{|c|}{$\begin{array}{l}\text { *Modest } \\
\text { ** Significant } \\
\text { ** Significant: Amounts given to the author's institution or to a colleague for research in which the author has participation, not directly to the } \\
\text { author. } \\
\text { Note: UFMG = Universidade Federal de Minas Gerais, FHEMIG = Fundação Hospitalar do Estado de Minas Gerais; CNPq = Conselho Naciona } \\
\text { de Desenvolvimento Cientifico e Tecnológico; FAPEMIG = Fundação de Amparo à Pesquisa do Estado de Minas Gerais. } \\
\text { For more information, see Instructions for Authors. }\end{array}$} \\
\hline
\end{tabular}




\section{References}

1. Brune C, Kim SJ, Salt J, Leventhal BL, Lord C, Cook EH Jr. 5-HTTLPR Genotype-Specific Phenotype in Children and Adolescents with Autism. Am J Psychiatry. 2006;163(12):2148-56.

2. Szatmari P, Paterson AD, Zwaigenbaum L, Roberts W, Brian J, Liu XQ, Vincent JB, Skaug JL, Thompson AP, Senman L, Feuk L, Qian C, Bryson SE, Jones MB, Marshall CR, Scherer SW, Vieland VJ, Bartlett C, Mangin LV, Goedken R, Segre A, Pericak-Vance MA, Cuccaro ML, Gilbert JR, Wright HH, Abramson RK, Betancur C, Bourgeron T, Gillberg C, Leboyer M, Buxbaum JD, Davi KL, Hollander E, Silverman JM, Hallmayer J, Lotspeich L, Sutcliffe JS, Haines JL, Folstein SE, Piven J, Wassink TH, Sheffield V, Geschwind DH, Bucan M, Brown WT, Cantor RM, Constantino JN, Gilliam TC, Herbert M, Lajonchere C, Ledbetter DH, Lese-Martin C, Miller J, Nelson S, Samango-Sprouse CA, Spence S, State M, Tanzi RE, Coon H, Dawson G, Devlin B, Estes A, Flodman P, Klei L, McMahon WM, Minshew N, Munson J, Korvatska E, Rodier PM, Schellenberg GD, Smith M, Spence MA, Stodgell C, Tepper PG, Wijsman EM, Yu CE, Rogé B, Mantoulan C, Wittemeyer K, Poustka A, Felder B, Klauck SM, Schuster C, Poustka F, Bölte S, Feineis-Matthews S, Herbrecht E, Schmötzer G, Tsiantis J, Papanikolaou K, Maestrini E, Bacchelli E, Blasi F, Carone S, Toma C, Van Engeland H, de Jonge M, Kemner C, Koop F, Langemeijer M, Hijmans C, Staal WG, Baird G, Bolton PF, Rutter ML, Weisblatt E, Green J, Aldred C, Wilkinson JA, Pickles A, Le Couteur A, Berney T, McConachie H, Bailey AJ, Francis K, Honeyman G, Hutchinson A, Parr JR, Wallace S, Monaco AP, Barnby G, Kobayashi K, Lamb JA, Sousa I, Sykes N, Cook EH, Guter SJ, Leventhal BL, Salt J, Lord C, Corsello C, Hus V, Weeks DE, Volkmar F, Tauber M, Fombonne E, Shih A, Meyer KJ. Mapping autism risk loci using genetic linkage and chromosomal rearrangements. Nat Genet. 2007;39(3):319-28.

3. Abrahams BS, Geschwind DH. Advances in autism genetics: on the threshold of a new neurobiology. Nat Rev Genet. 2008;9(5):341-55.

4. Bartlett CW, Gharani N, Millonig JH, Brzustowicz LM. Three autism candidate genes: a synthesis of human genetic analysis with other disciplines. Int J Dev Neurosci. 2005;23(2-3):221-34.

5. Prathikanti S, Weinberger DR. Psychiatric genetics - the new era: genetic research and some clinical implications. Br Med Bull. 2005;73-74:107-22.

6. Calkins ME, Dobie DJ, Cadenhead KS, Olincy A, Freedman R, Green MF, Greenwood TA, Gur RE, Gur RC, Light GA, Mintz J, Nuechterlein KH, Radant AD, Schork NJ, Seidman LJ, Siever LJ, Silverman JM, Stone WS, Swerdlow NR, Tsuang DW, Tsuang MT, Turetsky BI, Braff DL. The consortium on the genetics of endophenotypes in schizophrenia: model recruitment, assessment, and endophenotyping methods for a multisite collaboration. Schizophr Bull. 2007;33(1):33-48.

7. Gur RE, Calkins ME, Gur RC, Horan WP, Nuechterlein KH, Seidman LJ, Stone WS. The consortium on the genetics of schizophrenia: neurocognitive endophenotypes. Schizophr Bull. 2007;33(1):49-68.

8. Golarai G, Grill-Spector K, Reiss AL. Autism and the development of face processing. Clin Neurosci Res. 2006;6(3):145-60.

9. Hall GB, Szechtman H, Nahmias C. Enhanced salience and emotion recognition in autism: a PET study. Am J Psychiatry. 2003;160(8):1439-41.

10. Piven J, Palmer P, Jacobi D, Childress D, Arndt S. Broader autism phenotype: evidence from a family history study of multiple-incidence autism families. Am J Psychiatry. 1997;154(2):185-90.

11. Ashwin C, Baron-Cohen S, Wheelwright S, O'riordan M, Bullmore ET. Differential activation of the amygdala and "social brain" during fearful face processing in Asperger Syndrome. Neuropsychologia. 2007;45(1):2-14.

12. Lindner JI, Rósen LA. Deconding of emotions through facial expression, prosody and verbal content in children and adolescentes with Asperger's Syndrome. J Autism Dev Disord. 2006;36(6):769-77.

13. Bolte $S$, Poustka F. The recognition of facial affect in autistic and schizophrenic subjects and their first-degree relatives. Psychol Med. 2003;33(5):907-15.

14. Kohler CG, Turner TH, Gur RE, Gur RC. Recognition of facial emotions in neuropsychiatric disorders. CNS Spectr. 2004;9(4):267-74.

15. Rieffe C, Meerum Terwogt M, Kotronopoulou K. Awareness of single and multiple emotions in high-functioning children with autism. J Autism Dev Disord. 2007;37(3):455-65.

16. Adolphs R, Spezio ML, Parlier M, Piven J. Distinct face-processing strategies in parents of autistic children. Curr Biol. 2008;18(14):1090-3.

17. Palermo R, Rhodes G. Are you always on my mind? A review of how face perception and attention interact. Neuropsychologia. 2007;45(1):75-92.

18. Gottesman II, Gould TD. The endophenotype concept in psychiatry: etymology and strategic intentions. Am J Psychiatry. 2003;160(4):636-45.
19. Braff DL, Freedman R, Schork NJ, Gottesman II. Deconstructing schizophrenia: an overview of the use of endophenotypes in order to understand a complex disorder. Schizophr Bull. 2007;33(1):21-32.

20. Canli T, Lesch KP. Long story short: the serotonin transporter in emotion regulation and social cognition. Nat Neurosci. 2007;10(9):1103-9.

21. Hariri AR, Mattay VS, Tessitore A, Kolachana B, Fera F, Goldman D, Egan MF, Weinberg DR. Serotonin transporter genetic variation and the response of the human amygdala. Science. 2002;297(5580):400-3.

22. Hariri AR, Holmes A. Genetics of emotional regulation: the role of the serotonin transporter in neural function. Trends Cogn Sci. 2006;10(4):182-91.

23. Pezawas L, Meyer-Lindenberg A, Drabant EM, Verschiski BA, Munoz KE, Kolchana BS, Egan MF, Mattay VS, Hariri AR, Weinberger DR. 5HTTLPR polymorphism impacts human cingulate-amygdala interactions: a genetic susceptibility mechanism for depression. Nat Neurosci. 2005;8(6):828-34.

24. Huang $\mathrm{CH}$, Santangelo SL. Autism and serotonin transporter gene polymorphisms: A systematic review and meta-analysis. Am J Med Genet B Neuropsychiatr Genet. 2008; 147B:903-913.

25. Tordjman S, Gutknecht L, Carlier M, Spitz E, Antoine C, Slama F Carsalade V, Cohen DJ, Ferrari P, Roubertoux PL, Anderson Gm. Role of the serotonin transporter gene in the behavioral expression of autism. Mol Psychiatry. 2001;6(4):434-9.

26. Amorim P. Mini International Neuropsychiatric Interview (MINI): validation of a short structured diagnostic psychiatric interview. Rev Bras Psiquiatr. 2000;22:(3) 106-15.

27. Kohler CG, Turner TH, Warren BS, Bilker B, Bresinger CM, Siegel SJ, Kanes SJ, Gur RE, Gur RC. Facial emotion recognition in schizophrenia: intensity effects and error pattern. Am J Psychiatry. 2003;160(10):1768-74.

28. Gur RC, Ragland JD, Moberg PJ, Turner TH, Bilker WB, Kohler C, Siegel SJ, Gur RE. Computerized neurocognitive scanning: I. Methodology and validation in healthy people. Neuropsychopharmacology. 2001;25(5):766-76.

29. Campi-Azevedo AC, Boson W, De Marco L, Romano-Silva MA, Correa H. Association of the serotonin transporter promoter polymorphism with suicidal behavior. Mol Psychiatry. 2003;8(11):899-900.

30. Carter CS, Barch DM, Gur R, Gur R. Pinkham A, Ochsner K. CNTRICS final task selection: social cognitive and affective neuroscience-based measures. Schizophr Bull. 2009;35(1):153-62.

31. Battaglia M, Ogliari A, Zanoni A, Citterio A, Pozzoli U, Giorda R, Maffei $\mathrm{C}$, Marino $\mathrm{C}$. Influence of the serotonin transporter promoter gene and shyness on children's cerebral responses to facial expressions. Arch Gen Psychiatry. 2005;62(1):85-94.

32. Adolphs, R. Neural systems for recognizing emotion. Curr Opin Neurobiol. 2002;12(2):169-77.

33. Adolphs R, Gosselin F, Buchanan TW, Tranel D, Schyns P, Damasio AR. A mechanism for impaired fear recognition after amygdala damage. Nature. 2005;433(7021):68-72

34. Spezio ML, Adolphs R, Hurley RSE, Piven J. Abnormal use of information in high-functioning autism. J Autism Dev Disord. 2007;37(5):929-39.

35. Critchley HD, Daly EM, Bullmore ET, Williams SC, Van Amelsvoortt, Robertson DM, Rowe A, Phillips M, Mclongan G, Howlin P, Murphy DG. The functional neuroanatomy of social behavior: Changes in cerebral blood flow when people with autistic disorder process facial expressions. Brain. 2000;123(11):2203-12.

36. Greimel E, Schulte-Rüther M, Kircher T, Kamp-Becker I, Remschmidt H, Fink GR, Herpertz-Dahlmann B, Konrad K. Neural mechanisms of empathy in adolescents with autism spectrum disorder and their fathers. Neuroimage. 2010;49(1):1055-65.

37. Mier D, Lis S, Neuthe K, Sauer C, Esslinger C, Gallhofer B, Kirsch P. The involvement of emotion recognition in affective theory of mind. Psychophysiology. 2010;47(6):1028-39

38. Harmer CJ, Rogers RD, Tunbridge E, Cowen PJ, Goodwin GM. Tryptophan depletion decreases the recognition of fear in female volunteers. Psychopharmacology (Berl). 2003;167(4):411-7.

39. Attenburrow MJ, Williams C, Odontiadis J, Reed A, Powell J, Cowen PJ, Harmer CJ. Acute administration of nutritionally sourced tryptophan increases fear recognition. Psychopharmacology (Berl). 2003;169(1):104-7.

40. Parra FC, Amado RC, Lambertucci JR, Rocha J, Antunes CM, Pena SD. Color and genomic ancestry in Brazilians. Proc Natl Acad Sci U S A 2003;100(1):177-82. 